\section{Praktisk og nyttig verktøy i samtale med barn om sorg}

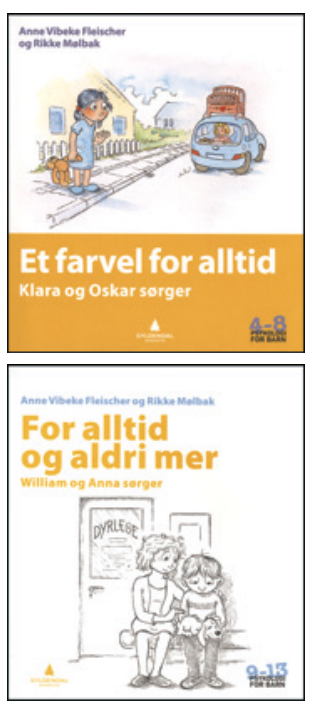

Anne Vibeke Fleischer, Rikke Mølbak Et farvel for alltid

Klara og Oscar sørger. 55 s, ill. Oslo:

Gyldendal Akademisk, 2014. Pris NOK 168 ISBN 978-82-05-45196-4

Anne Vibeke Fleischer, Rikke Mølbak

\section{For alltid og aldri mer}

William og Anna sørger. 56 s, ill. Oslo:

Gyldendal Akademisk, 2014. Pris NOK 168

ISBN 978-82-05-45197-1

Et farvel for alltid (barn 4-8 år) og For alltid og aldri mer (barn 9-13 år) er skrevet for barn som opplever sorg, og for barn som trenger å forstå sorg hos andre barn. Bøkene, som anbefales lest sammen med en voksen, er pedagogisk oppbygd, med korte historier som gir et innblikk i hvordan barn opplever ulike former for tap og sorg. Det er laget oppfølgingsspørsmål til historiene, noe som skal gi grunnlag for samtaler om hva sorg er og hvordan sorg kan oppleves. Det finnes en rekke fine illustrasjoner, og hver bok avsluttes med etterord for voksne.

Selv om tidlige teoretikere sådde tvil om barns forutsetninger for å sørge, er det nå bred enighet om at både små og store barn sørger og trenger forståelse for sin måte å sørge på. Disse utgivelsene har et tydelig barneperspektiv, og det overordnede fokus er betydningen av å anerkjenne og akseptere barns opplevelser og vanskelige følelser, i motsetning til voksnes velmenende, men ofte litt feilslåtte forsøk på å trøste og skåne barn. Historiene er engasjerende og gir et lite, men fint innblikk i hvordan små og store hendelser i et barns liv kan gi opphav til ulike sorgreaksjoner. De korte historiene går ikke i dybden, men skal danne grunnlag for mer utdypende samtaler, noe jeg tror de kan bidra til hvis den voksne klarer å opprettholde en åpen, lyttende og aksepterende holdning til det barn forteller. Språket er lett forståelig for både voksne og barn, selv om enkelte ord etter undertegnedes mening ikke egner seg så godt i barnebøker (f.eks. «liket»).

I etterord for voksne er det mange kloke beskrivelser. I den grad jeg savner noe, kunne det vært beskrevet mer eksplisitt at barn ofte mestrer sorg ved å unnvike vanskelige tanker og følelser, noe som kan føre til at voksne undervurderer barns sorg. Barns behov utover behovet for følelsesmessig bearbeiding av sorgen kunne vært nevnt, f.eks. betydningen av å opprettholde normale rutiner i hverdagen. Det kunne også vært en kortfattet oversikt over når det er behov for profesjonell hjelp. Noen barn er mer sårbare enn andre, og noen tap er mer dramatiske (f.eks. brått, uventet dødsfall i nær familie), noe som øker risikoen for en fastlåst sorg. Avsnittet «Skal barnet gå i terapi?» virker således noe overfladisk og lite konkret.

Disse to små publikasjonene kan anbefales både i enesamtaler med barn, og i barnehager og skoleklasser når sorg som tema blir satt på dagsordenen.

Pål Kristensen

Psykolog, Barne- og ungdomspsykiatrisk seksjon

Sykehuset Telemark

\section{Tradisjonell kinesisk medisin}

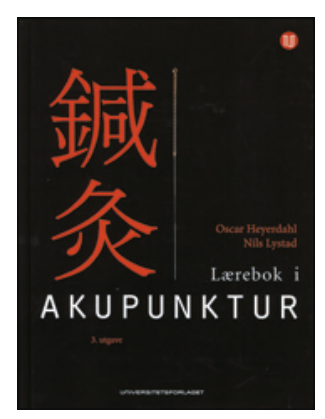

\author{
Oscar Heyerdahl, Nils Lystad \\ Lærebok i akupunktur \\ 3. utg. 397 s, tab, ill. Oslo: Universitetsforlaget, \\ 2013. Pris NOK 699 \\ ISBN 978-82-15-02120-1
}

Begge forfatterne er leger, og bakgrunnen for utgivelsen er mange års erfaring med akupunkturkurs for helsepersonell. Boken er delt i seks deler, der de to første gir en gjennomgang av aktuell akupunkturforskning. De øvrige delene omhandler tradisjonell kinesisk medisin og praktisk akupunkturbehandling med dette som fundament.

Forfatternes begrunnelse for å beholde tradisjonell kinesisk medisin som ramme for læreverket, og ikke plassere akupunkturen innenfor en vestlig medisinsk tilnærming, er at det «er fare for at noen av barna da forsvinner ut med badevannet». Jeg tolker dette dit hen at forfatterne mener at tradisjonell kinesisk medisin kan bidra med kunnskap som ennå ikke er erkjent i vestlig medisin. Beskrivelsen er grundig og detaljert, og omhandler innledningsvis begreper som Yin og Yang, Qi, akupunkturmeridianer og -punkter. Videre gis en detaljert innføring i hvordan tradisjonell kinesisk akupunktur kan benyttes i daglig praksis. Litt over 300 av nesten 400 sider er viet dette.

Det innledes med en relativt omfattende gjennomgang av forskning på akupunktur. Forfatterne refererer mange sentrale studier, men gjennomgangen bærer preg av at agendaen er å bevise at det finnes et forskningsmessig grunnlag for akupunktur.

Det er forsket en god del på akupunktur, men mye av forskningen er metodisk svak. Et sentralt problem er at begrepet akupunktur er dårlig definert. Svært mange forskjellige intervensjoner kalles akupunktur i forskningssammenheng, fra så vidt å penetrere huden med en nål til kraftig elektrisk stimulering uten nåler. Pragmatiske randomiserte kontrollerte studier synes å vise at akupunkturbehandling kan ha klinisk effekt. Imidlertid sier disse studiene intet om hvor stor del av effekten som kan tilskrives selve nålestikket og tradisjonell kinesisk medisin, og hva som skyldes ikke-spesifikke effekter/placeboeffekter.

Forskning antyder at nålestikket kan ha en viss spesifikk effekt, blant annet ved smertetilstander, men ingen forskning viser klart at det har klinisk betydning at nålene er satt etter reglene i tradisjonell kinesisk medisin. Behandlingssituasjonen hos en akupunktør, der man blant annet gis en diagnose og får behandling innenfor et særegent medisinsk system, kan antas å gi uttalte ikke-spesifikke effekter. Det synes godt dokumentert at den overveiende delen av effekten av behandlingen beror på slike effekter.

Om man ønsker å sette seg inn i tradisjonell kinesisk medisin og benytte akupunktur med den som teoretisk fundament, er dette en utmerket lærebok. Tiden er imidlertid etter min mening moden for å erkjenne at akupunktur i det alt vesentlige baserer seg på ikkespesifikke effekter, også kalt placeboeffekter. Disse har stor betydning i det meste av medisinsk behandling, og man bør nå sette søkelyset på hvordan man best mulig kan stimulere og aktivere disse effektene hos den enkelte pasient.

Jeg tror det er på tide å tappe ut badevannet.

Einar Kristian Borud

Overlege, Kontor for militærmedisinsk epidemiologi

Forsvarets sanitet 